University of Miami Law School University of Miami School of Law Institutional Repository

1994

\title{
Interpreting Oriental Cases: The Law of Alterity in the Colonial Courtroom
}

Kunal Parker

University of Miami School of Law, kparker@law.miami.edu

Follow this and additional works at: https://repository.law.miami.edu/fac_articles

Part of the Legal History Commons

\section{Recommended Citation}

Kunal Parker, Interpreting Oriental Cases: The Law of Alterity in the Colonial Courtroom, 107 Harv. L. Rev. 1711 (1994).

This Article is brought to you for free and open access by the Faculty and Deans at University of Miami School of Law Institutional Repository. It has been accepted for inclusion in Articles by an authorized administrator of University of Miami School of Law Institutional Repository. For more information, please contact library@law.miami.edu. 


\section{INTERPRETING ORIENTAL CASES: THE LAW OF ALTERITY IN THE COLONIAL COURTROOM}

\section{INTRODUCTION: READING AND JUDGING}

Sir Erskine Perry, Chief Justice of Her Majesty's Supreme Court in Bombay from I847 to 1852 , opens a collection of cases of "Indian or Colonial interest" ${ }^{\prime}$ decided by him with the following observation:

The insight into human life afforded by transactions in a Court of Justice had always appeared to me to give peculiar opportunities to an observer for studying national character; but it is especially to a class like the English in India that such opportunities are most valuable. For the chief administrators in our vast Indian empire are so completely severed from the bulk of the population by colour, race, language, religion, and material interests, that they are often, if not habitually, in complete ignorance of the most patent facts occurring around them. But in courts of justice the veil which shrouds the privacy of Oriental life is necessarily drawn aside, the strong ties which at other times bind together cast and family in pursuit ot [sic] a common object are loosende [sic] under the pressure of stronger individual interests, and there, amidst masses of conflicting testimony, ... the motives, reasonings, and actions of the native population of India are displayed in broad light and may be traced with inestimable advantage. ${ }^{2}$

Published in London in 1853 under the title Cases Illustrative of Oriental Life, and known to legal historians simply as Oriental Cases, this collection of mid-nineteenth-century judicial opinions is of interest for two reasons. First, colonial legal discourse appears to have escaped almost entirely the massive critical reexamination of colonial discourse that followed the publication of Edward Said's Orientalism in 1978 . However, even a cursory inspection of the paragraph quoted above suggests that Oriental Cases fits squarely within Said's definition of Orientalism as "the corporate institution for dealing with the Orient dealing with it by making statements about it, authorizing views of it, describing it, by teaching it, settling it, ruling over it . . .".3 This Note attempts, therefore, to draw the attention of critics to colonial legal discourse as an important constituent of the corpus of Orientalist writings on India.

I Erskine Perry, Cases Illustrative of Oriental Life Decided in H.M. Supreme COURT at Bombay: The Application OF ENGLish LaW to INDIA at v (photo. reprint 1988) (1853).

2 Id. at iii-iv (footnote omitted).

3 EdWARd W. SAID, ORIENTALISM 3 ( 1978 ). 
Second, having situated Oriental Cases within the framework of Orientalism, one must ask how it operates as an Orientalist text. The text's self-consciously "illustrative" aspirations attract attention instantly. To a student of the law, the violent visual metaphor of using the power of the law to draw aside "the veil which shrouds the privacy of Oriental life" - in other words, of disrobing the Orient through the law - is intriguing. Generally speaking, the law does not "illustrate" the parties that stand before it, but structures and resolves the disputes they bring to it. Even the fields of comparative law and law and anthropology, both of which attempt "illustrations" of one kind or another, study the law as it is located within societies and as an artifact of societies. Unlike these fields, however, Oriental Cases attempts to "illustrate" the Orient through the law. The judge peers through his own laws, the laws of the colonizer, to "illustrate" a foreign society, the colonized. The law is therefore not an object of study but a methodology or means of "illustration." It is a type of filter or lens permitting a peculiar kind of reading - the reductive transformation of a social text constructed in a courtroom into an "illustrative" Orientalist ethnography.

What makes the colonial courtroom an exemplary site for reading? The passage quoted above suggests two answers. First, at least in the r840s, the courtroom is one of the few points on the extensive border between colonizer and colonized where some form of communicative exchange exists. The relative scarcity of other points of contact makes it vital that readings thus procured be transmitted to the "chief administrators in our vast Indian empire" who are "so completely severed from the bulk of the population." Therefore, the law in the I840s performs a function that is later performed by modern visual-interpretive disciplines such as anthropology. ${ }^{4}$ Second, crises originating within the colonized population gravitate toward the colonial courtroom, where they explode and offer themselves up for reading. But for the colonial judge, these particularly revealing moments of crisis - the unraveling of the "strong ties which at other times bind together cast and family" - would remain unread.

${ }^{4}$ Although disciplines such as anthropology and history detached themselves from the courtroom as the nineteenth century wore on, they continued to assist courts in the business of judging. This is abundantly illustrated by the passage in 1872 of the Indian Evidence Act (Act I of I872). The penultimate paragraph of $\S 57$ of the Act lists matters of which judicial notice shall be taken. Thus, "on all matters of public history, literature, science or art, the Court may resort for its aid to appropriate books or documents of reference." Indian Evidence Act of 1872 (Act I of 1872), § 57, reprinted in JOHN WOODROFFE, WOODROFFE AND AMEER ALI's LAW OF EVIDENCE APPLICABLE To BRITISH INDIA 467-69 (8th ed. 1925). This leading Indian textbook on the law of evidence lists the ethnographic and historical texts relied upon by Anglo-Indian courts to assist them in the business of judging. The list comprises almost every text on India that acquired canonical status under colonial rule. See id. at 474-76. The relationship between systematized bodies of colonial knowledge and colonial law undoubtedly contains a riveting story, but one that is beyond the scope of this Note. 
However, Oriental Cases does not stand for the naive proposition that law is a transparent lens that enables unproblematic, unmediated readings of crisis-stricken "natives." On the contrary, the text is acutely conscious of the law's limitations as a lens, of its occasional opacity, of its ability to sanction misreadings. Misreadings are particularly worrisome, not only because they may be reproduced as "false" Orientalist knowledge, but also because they may mislead the judge (who belongs, after all, to the class of "chief administrators in our vast Indian empire") in the business of judging - forcing the social text constructed in the courtroom into legal categories. Therefore, when the law contains obstacles - for example, rules permitting "masses of conflicting testimony" - such obstacles may distort the judge's reading and threaten the precision of his judgment.

Obstacles to reading are harmless when reading is itself unnecessary. However, this can only happen when the judge operates within his own society. Back in England, judges may dispense with reading because they share with the parties before them "a common religion, a common mother tongue, and a unity of race - the national opinions and prejudices, with the knowledge of an infinite number of facts which are too familiar to all present to form subject of remark . . ." These happy commonalities enable the English judge in England to surmount legal obstacles to reading such as "[t]he weight due to testimony" that, in India, can be disturbingly obfuscatory. What remains as the business of the courtroom in England is pure judging. And judging is itself pure, automatic, unerring, infallible. Complete commonality between the judge and the parties "point [s] conclusively to the decision, which the audience as well as the Bench are irresistibly led to adopt."?

In India, by contrast, colonial law operates on the heavily guarded border between the hermetic categories of colonizer and colonized. Therefore, reading - as a self-conscious and aggressive operation must always exist to penetrate the category of the colonized. But reading is always profoundly destabilized by its origins in the divide between colonizer and colonized, which first imprisons the colonized behind a veil of unreadability (in other words, within the category of the colonized) and then sanctions reading operations designed to "draw aside" this veil. Therefore, the failure of any individual act of reading (and of the individual act of judging associated with it) may be attributed not only to the dangers of reading through the occasionally turbid lens of the law, but also to a more fundamental inability to read through the scrupulously maintained divide between colonizer

\footnotetext{
5 PERRY, supra note $\mathrm{I}$, at iv.

${ }^{6}$ Id.

${ }^{7}$ Id. (emphasis added).
} 
and colonized. Predictably enough, this inability is transposed onto the colonized themselves, so that they become irreducibly, even genetically, unreadable. Accordingly, Oriental Cases complains that "as the knowledge of native manners increases [so] do the difficulties which impede an English official in the administration of justice become embarrassing." 8 Therefore, the fundamentally unreadable are also fundamentally unjudgeable. While the English judge in England judges infallibly by virtue of complete cultural commonality with the parties before him, "guides to the judgment are either wholly wanting or are transfigured to the Anglo-Saxon who is dispensing justice to Hindus, Musalmáns, and Parsis." Hence, the judge of Oriental Cases must approach both reading and judging with equal degrees of caution.

It is against this backdrop that the "illustrations" of Oriental Cases must be received. Before they may be examined in greater depth, however, it is essential to situate Oriental Cases within its historical context.

\section{Theoretical Perspectives and an AbBreviated HISTORY OF ANGLO-INDIAN LAW}

It is of critical importance to recast the history of Anglo-Indian law ${ }^{10}$ as a narrative of violence to territory, text, and person that must always supplement - if not supplant - the mission civilisatrice narrative of British rule. The foundation of the legal system that produced Oriental Cases dates to the Battle of Plassey in 1757 and the East India Company's subsequent acquisition of control over the Mughal provinces of Bengal, Bihar, and Orissa. The first judicial plan devised in $\mathrm{I} 772$ by Warren Hastings, the first Governor-General of Bengal, assured Hindu and Muslim inhabitants of the newly won provinces that their "personal laws" - a colonial term, encompassing the laws of inheritance, marriage, religious usage, and so on - would be governed by the "Shaster" and the Koran, respectively. ${ }^{11}$ This first ritual incantation promising to protect the personal laws of Indians would be repeated throughout the nineteenth century. Native Law Officers - pundits in the case of Hindus and maulvies in the case of Muslims - were attached to Anglo-Indian courts to declare the sacred laws of both religious communities to English judges in order to minimize violence to these laws.

$8 I d$. (emphasis added).

${ }^{9}$ Id.

${ }^{10}$ For more comprehensive accounts of Anglo-Indian law, see generally J. DUNCAN DERRETt, Religion, LAW aNd the State in INDia passim (ig68), and M.P. JAIN, OUTLines of INDIAN LEGAL HISTORY passim (I990).

11 See JAIN, supra note io, at 6r. The term "Shaster" refers to the entire corpus of Hindu religious-legal texts and commentaries. 
Almost immediately, however, it was felt that the Native Law Officers were untrustworthy. "I can no longer bear to be at the mercy of our pundits," Sir William Jones confesses in a private letter, "who deal out Hindu law as they please, and make it at reasonable rates, when they cannot find it ready made."12 So began the momentous process of controlling sacred legal texts through translation, from which the textual Orientalist tradition of British India descends. Translations were inevitably accompanied by the marginalization of Native Law Officers, the invasion and colonization of legal "space" by dislodging and disempowering local tribunals, the imposition of English procedural requirements upon cases, the surreptitious incorporation of English legal standards into Hindu and Muslim law, and an as yet undocumented process of judicial legislation that has escaped the scrutiny of contemporary historians almost entirely.

More important for purposes of this Note is Anglo-Indian law's treatment of the vast body of unwritten customary law that had long governed the lives of many communities, but that often differed substantially from the textual law administered by English judges. Undoubtedly motivated by established attitudes of distrust toward Indian litigants, but also by the traditional hostility of English courts to customs claimed to derogate from settled law, Anglo-Indian courts required Indian litigants to "prove" the validity of hitherto unwritten customs according to the highly stringent evidentiary test articulated in the eighteenth-century Commentaries of Sir William Blackstone with respect to local customs in England. According to the test, a local custom had to meet the following seven requisites in order to be recognized as legally valid: the custom must have been so long used "that the memory of man runneth not to the contrary"; 13 it must have been continuously followed; it must have been peaceable, and acquiesced in; it must be reasonable; it must be certain; although established by consent, it must be compulsory; and lastly, customs must be consistent with each other. ${ }^{14}$

Indian litigants' attempts to "prove" the existence of customs under Blackstone's test resulted in the construction in the courtroom of a massive social text especially suited to judicial reading operations. Nevertheless, despite the importance of custom as a field for the launching of such operations, the history of custom in the nineteenth

12 Letter from Sir William Jones to Charles Chapman (Sept. 28, I785) in 2 THE LETTERS of Sir William Jones 683-84 (Garland Cannon ed., 1970).

13 I William Blackstone, Commentaries *76. In Blackstone's test, the "memory of man" referred to legal memory, which ran as far back as the reign of Richard the First. See id. at *76 n. Io. Anglo-Indian courts modified this definition, so that legal memory ran back to the establishment of the Supreme Court of Calcutta in I773. See Ashutosh Mukerjee, Customs and Customary Law, 9 Bombay L. REP. J. 225, 243 (1907).

${ }^{14}$ See BLACKSTONE, supra note 13 , at * $76-* 78$. 
century is one of depredation at the hands of textual law, as an ever greater number of individuals were subjected to texts identified, translated, elevated, interpreted, and applied by Anglo-Indian judges. This story remains untold and is in danger of slipping into oblivion - the only exhaustive treatment of the role of custom in Anglo-Indian law is Sripati Roy's largely uncritical Custom and Customary Law in British India, published in I9II. ${ }^{15}$ Nonetheless, the story is an instance of a violent wielding of Orientalist texts against the colonized.

This account of the history of Anglo-Indian law shows that the violent visual metaphor that opens Oriental Cases is girded by "real" violence, which sanctions the invocation of a broader philosophical critique of violence, law, and justice. In Critique of Violence (Zur Kritik der Gewalt), Walter Benjamin states that "[t]he task of a critique of violence can be summarized as that of expounding its relation to law and justice."16 Jacques Derrida describes Benjamin's distinction between two kinds of violence in law: "the founding violence, the one that institutes and positions law (die rechtsetzende Gewalt, 'law making violence') and the violence that conserves, the one that maintains, confirms, insures the permanence and enforceability of law (die rechtserhaltende Gewalt, 'law preserving violence')."17 For Benjamin, violence that is neither law-founding nor law-preserving "forfeits all validity."18 Derrida, on the other hand, unearths brilliantly the inherent invalidity of law-founding violence - invalid precisely because it must always, by definition, precede law:

In these situations said to found law (droit) or state, the grammatical category of the future anterior all too well resembles a modification of the present to describe the violence in progress. It consists, precisely, in feigning the presence or simple modalization of presence

These moments, supposing we can isolate them, are terrifying moments. Because of the sufferings, the crimes, the tortures that rarely fail to accompany them, no doubt, but just as much because they are in themselves, and in their very violence, uninterpretable or indecipherable. ${ }^{19}$

15 SRIPati Roy, Customs and Customary Law in British India passim (igir). This Note does not suggest that Anglo-Indian legal commentators were unaware of the increasing textualization of Anglo-Hindu and Anglo-Muslim law. At least one late nineteenth-century legal commentator mounted a scathing attack upon Anglo-Indian law precisely for its excessive reliance upon text. See J.H. NELSON, A VIEW OF THE HiNdU LAW AS ADMINISTERED BY THE HIGH Court of MADRAS passim (I877). Nonetheless, there exist no comprehensive legal (or social) histories of the fate of customary law in the nineteenth century.

16 Walter Benjamin, Critique of Violence, in Reflections: Essays, Aphorisms, Autobiographical Writings 277, 277 (Peter Demetz ed. \& Edmund Jephcott trans., 1986).

17 Jacques Derrida, Force of Law: The "Mystical Foundation of Authority," II Cardozo L. REv. 919, 981 (Mary Quaintance trans., 1990).

18 BENJAMIN, supra note 16 , at 287.

19 Derrida, supra note 17 , at 991 . 
Later, Derrida collapses Benjamin's distinction between law-founding violence and law-preserving violence:

I shall propose the interpretation according to which the very violence of the foundation or position of law (Rechtsetzende Gewalt) must envelop the violence of conservation (Rechtserhaltende Gewalt) and cannot break with it. It belongs to the structure of fundamental violence that it calls for the repetition of itself and founds what ought to be conserved, conservable, promised to heritage and tradition, to be shared. . . . Conservation in its turn refounds, so that it can conserve what it claims to found. Thus there can be no rigorous opposition between positioning and conservation . . . .20

In other words, Derrida argues that instances of law-preserving violence carry within themselves instances of law-founding violence, typically justifying themselves through recourse to the "mythical foundations" of law-founding violence (which, by definition, are always constructed after the actual founding). ${ }^{21}$

Both Benjamin and Derrida are concerned with the problem of violence and law in "the European model of bourgeois, liberal, parliamentary democracy."22 British India was neither bourgeois, nor liberal, nor parliamentary, nor democratic. Nonetheless, Derrida's framework lends itself easily to Anglo-Indian law. It is historically incontestable that there was an essentially "indecipherable" law-founding violence at the origin of Anglo-Indian law, even if only from the perspective of the colonized. Before examining whether this lawfounding violence replicates itself in subsequent instances of lawpreserving violence (or, more broadly defined, everyday instances of adjudication), however, it is essential to identify the foundational myths of Anglo-Indian law to which all of its judicial performances returned. The most obvious of these is Anglo-Indian law's repeated assurance that it was administering to Indians their "own" laws - a myth of continuity and non-disruption. ${ }^{23}$

Yet Anglo-Indian law raised the banner of non-disruption to embark upon a massive reading operation encompassing both the con-

20 Id. at 997 .

21 In the American context, these mythical foundations often consist of the "original intent" of the Framers of the Constitution or "the plain meaning of the words" of the Constitution. See, e.g., Drucilla Cornell, The Violence of the Masquerade: Law Dressed Up As Justice, I I CARDozo L. REv. I047, IO5 I-6I (employing Derrida's analysis to deconstruct the U.S. Supreme Court's reliance upon "original intent" and "plain meaning" to uphold a Georgia anti-sodomy law in Bowers v. Hardwick, 478 U.S. 186 (1986)).

22 Derrida, supra note $x 7$, at 979 .

${ }^{23}$ However, even Anglo-Indian law's most sympathetic and non-disruptive moment - that of valorizing and defending Hindu law texts - was founded upon a notion of the essential alterity of the people that produced those texts, and of those texts themselves. See Jenny Sharpe, The Violence of Light in the Land of Desire; or, How William Jones Discovered India, 20 BOUNDARY 2, at 26, 36-37 (I993). 
tainment of the personal laws of Hindus and Muslims in English translations, codes, and treatises and the deployment of Blackstone's evidentiary test against unwritten customary law. The myth of nondisruption therefore licensed the construction of an enormous colonial text and legitimated reading operations into it. However, as suggested earlier, any self-conscious and aggressive attempt at reading is always founded upon the notion that what is read is fundamentally unreadable. At the heart of Anglo-Indian law's foundational myth of nondisruption, therefore, lurks another myth, one that permeates all of Orientalist discourse perhaps, but undoubtedly imbues Oriental Cases: a myth of unreadability. The myth of unreadability at the core of Anglo-Indian law is constitutive of and constituted by the construction of the colonized as irreducibly different. From it radiate myths of non-disruption and continuity and - as the consequence of both of these - the twin functions of reading and judging.

Anglo-Indian law performs its readings and judgings more or less uneventfully until it approaches the limits of its ability to read through the colonizer-colonized divide. It is then forced to invoke the myth of unreadability in a direct and unmediated fashion to produce judicial results. And unlike violence-concealing myths of readability and presence, ${ }^{24}$ the myth of unreadability always sanctions a dramatic celebration of law-founding violence exactly as suggested by Derrida.

\section{The KoJahs AND Memons' CASE}

Undoubtedly the most famous of the judgments in Oriental Cases, the I847 opinion in The Kojahs and Memons' Case ${ }^{25}$ is a classic instance of the uses of myth and violence. Classified as an "illustration" of "Mahomedan Succession," the Kojahs and Memons' Case turns on the conflict between the textual Koranic law of succession and an alleged customary law of succession derogating from it. The case arises under a variant of Warren Hastings' Plan of I772, which required Anglo-Indian courts to uphold and administer the laws of the two gigantic categories - Hindu and Mahomedan - into which the "natives" were divided. This legal framework embodies, therefore, the myth of non-disruption:

In the case of Mahomedans or Gentoos, ${ }^{26}$ their inheritance and succession . . . shall be determined, in the case of the Mahomedans, by the

${ }^{24}$ See supra p. I717.

25 Perry, The Kojahs and Memons' Case (Bombay S.C. 1847) in Cases Illustrative of ORIENTAL Life Decided in H.M. SUPReme Court at Bombay: The Application of ENGLISH LAW To INDIA, supra note $\mathrm{I}$, at IIo [hereinafter The Kojahs and Memons' Case]. The Kojahs and Memons' Case is reported at 4 Indian Dec. (Old Series) 707 (Bombay S.C. 1847).

${ }^{26}$ In the late nineteenth century, the word "Gentoo" was described as follows:

Gentoo is a corruption of the Portuguese Gentio, a Gentile. Dr. Fryer (Travels, 1672 to I68I) says 'the Gentues, the Portugal idiom for Gentiles, are the aborigines.' He appears 
laws and usages of the Mahomedans, and where the parties are Gentoos, by the laws and usages of the Gentoos, or by such laws and usages as the same would have been determined by if the suit had been brought and the action commenced in a native Court. ${ }^{27}$

The test to prove the existence of the custom in The Kojahs and Memons' Case consists of the familiar "seven requisites which Blackstone has laid down for the validity of an English custom."28

The Kojahs and Memons' Case involves two "particular sects of Mahomedans" - the Kojahs and the Memon Cutchees - who govern themselves by a customary rule of succession "nearly analogous to the Hindu rule of succession." 29 In the Kojahs' case, the plaintiff Hirbae brought suit to obtain a declaration from the Supreme Court of Bombay that "she, as a Mahomedan female, [was] entitled to the share in distribution of her father's property which is ordained in the Koran."30 The defendants, the executrixes of the will of the plaintiff's uncle (who had taken possession of the estate of the plaintiff's father upon the latter's death), averred the opposite:

[A]ll the parties to the suit belong to a certain exclusive sect or cast of Mahomedans called Kojahs, which has existed from time immemorial, separate and distinct from other bodies or sects of Mahomedans, and under the government of divers laws and customs peculiar to themselves, and differing in many respects from the laws and customs of the Mahomedans ....31

Under the customary law of succession governing the Kojahs, females were not entitled to any share of their father's estate. Therefore, the question in The Kojahs and Memons' Case is whether the Supreme Court may, in a case involving Mahomedans, give effect to a custom at variance with the rule laid down in the Koran.

The Kojahs and Memons' Case - which requires the parties to "prove" the existence of the custom - is obviously well-suited to reading and judging. But how susceptible are the Kojahs to a reliable reading upon which a more or less reliable judgment may be based?

to be the first English writer by whom the term was used; but before his time, Pietro del la Valle speaks of the Hindus as Gentile, following the example of the Portuguese. Notwithstanding those unquestionable authorities, Halhed (Gentoo, Code xxi, xxii.) supposes that the Portuguese borrowed the term Gentoo from the Sanskrit word Gunt, a sentient being.

EDWARD BALFOUR, I THE ENCYCLOPæDIA OF INDIA II89 (London, Bernard Quaritch $3 \mathrm{~d}$ ed. I885).

27 The Kojahs and Memons' Case, supra note 25 , at 123.

${ }^{28} \mathrm{Id}$. at $\mathrm{I} 20$ (typeface altered); see supra p. I7I5.

${ }^{29}$ The Kojahs and Memons' Case, supra note 25, at 110 . The similarity between the facts and questions of law involved in both cases is the reason they are combined and governed by a single judgment. However, the opinion devotes far more attention to the Kojahs than to the Memons, and therefore this Note deals only with its treatment of the Kojahs.

$30 \mathrm{Id}$. at III.

31 Id. 
Haunted by the foundational myth of unreadability, the opinion oscillates between a drive toward reading and an equally powerful counter-drive to maintain a fundamental unreadability. It is this battle between certainty and obscurity that structures the opinion and culminates in its eruption in a reenactment of law-founding violence.

\section{A. Reading}

Is reading in The Kojahs and Memons' Case different, by virtue of its specifically ethnographic character, from the familiar "statement of facts" encountered in judicial opinions? One of the distinguishing characteristics of ethnographic writing is that it is invariably a form of "writing back," of transforming readings acquired in the field into discourse addressed to a metropolitan audience. Therefore, if the implied reader ${ }^{32}$ of an ethnographic text may also be one of the ethnographer's interlocutors, the text is not, strictly speaking, ethnographic. At this most basic level, one may conclude that no "native," lawyer or litigant, could be the implied reader of The Kojahs and Memons' Case, because the "native" who could read The Kojahs and Memons' Case - let alone comprehend its references to European jurists (Thibaut, Austin, von Savigny) and its occasional erudite (and untranslated) quotations from Latin sources - did not exist in the I840s. 33

The fact that The Kojahs and Memons' Case meets this negative test is, of course, insufficient to mark it as an instance of ethnographic writing. However, the opinion contains specifically ethnographic passages embedded in a matrix of legal discourse. Johannes Fabian describes what he labels the "Ethnographic Present" - a temporal device unique to ethnographic discourse that permits ethnographers to make such statements as "The X are matrilineal" - as one of the devices employed by anthropology to distance itself temporally from its Other. Fabian writes:

The use of the present tense in anthropological discourse . . . marks a literary genre (ethnography)[,] reveal[ing] a specific cognitive stance towards its object, the monde commenté. It presupposes the givenness

32 Gerald Prince's seminal article on the implied reader posits that every text contains " $a$ zero-degree narratee" who knows "the tongue (langue) and the language(s) (langage[s]) of the narrator." Gerald Prince, Introduction to the Study of the Narratee, in READER-Response Criticism: From Formalism to Post-Structuralism 7, io (Jane P. Tompkins ed., ig8o). To know a tongue "is to know the meanings (dénotations) of all the signs that constitute it," although it does not necessarily "include knowledge of the connotations (the subjective values that have been attached to them)." Id.

${ }^{33}$ Cf. Gauri Viswanathan, Masks of Conquest: Literary Study and British Rule IN INDIA 44 ( 1989 ) (tracing the beginnings of education in English in India to the passage of the English Education Act of I835). Indians who had a grasp of the language sufficient to embark upon a career in the law did not appear for at least another twenty years. 
of the object of anthropology as something to be observed. The present tense is a signal identifying a discourse as an observer's language. ${ }^{34}$

When scoured for instances of the "Ethnographic Present," The Kojahs and Memons' Case yields passages that are almost detachable from the rest by virtue of their ethnographic nature. These passages represent the transformation into colonial knowledge of readings obtained through the examination of "a great many witnesses, comprising the chief and most intelligent members of the Kojah cast . . . , who told us all that they appeared to know themselves respecting their origin, history, habits, and religious opinions." 35 The "us" in this passage unquestionably refers to the judge-ethnographer, who interrogates his interlocutors for "all they appear to know." It is hardly surprising, then, that the text - after outlining its methodology - opens its announcement of the results of the reading operation with the "Ethnographic Present" in its most classic manifestation: "[t]he Kojahs are a small cast in Western India . . ." F6 From this point, the text proceeds to describe the Kojahs in the meticulous fashion of an ethnography. No detail - language, appearance, occupation, places of residence, history - is omitted. ${ }^{37}$ The fact that The Kojahs and Memons' Case continued to be cited verbatim as a source of information on the Kojahs more than sixty years after it had been written underscores the assiduity of its reading operation. ${ }^{38}$

Who are the Kojahs? The judge of The Kojahs and Memons' Case amasses details about the Kojahs, straining to fashion a dependable reading based upon "hard facts" that, he hopes, might assist him in arriving at an unerring result. Among other things, the following "reliable" facts emerge: the Kojahs "appear to have originally come from Sindh or Cutch" and "are now settled [in] Cutch, Kattiawar, and Bombay"; in Bombay, they number about two thousand; their occupations are "confined to the more subordinate departments of trade"; "by their own traditions, [they] were converted from Hinduism [to Islam] about four hundred years [earlier] by a Pír named Sadr Dín"; and "their chief reverence at the present time is reserved for Agha Khan, . . . whom they believe to be a descendant of the Pir, who converted them to Islam." 39 Most importantly, this profusion of facts achieves the ostensible goal of the reading operation at the impressive level of certainty assured by Blackstone's evidentiary test: 40

34 Johannes Fabian, Time and the Other: How Anthropology Makes Its Object 86 (I983) (citations omitted).

${ }^{35}$ The Kojahs and Memons' Case, supra note 25, at II (emphasis added).

36 Id. (emphasis added).

${ }^{37}$ See id. at II2-I4.

38 See, e.g., Roy, supra note $\mathrm{I}_{5}$, at $4 \mathrm{II}-\mathrm{I}_{4}$.

39 The Kojahs and Memons' Case, supra note 25 , at Ir2-13.

40 See id. at 120. 
the Kojahs have proved with "little or no conflicting testimony" that their custom of succession does in fact exist. ${ }^{41}$

However, having proved the existence of the custom, the judge must now approach the question of judging. Should he strike down the custom because it is in conflict with Koranic law, which governs the parties to the case, who are - by their own admission - Mahomedans? Or should he uphold the custom and prevent Koranic law from overriding it? The answer to these questions would seem to lie in the Koranic law itself, which supposedly governs all other aspects of the lives of the parties, provided the parties can be shown to be Mahomedans. Since the "self-image" of the Kojahs is by itself insufficient to establish their identity as Mahomedans, the law must embark upon a second reading operation.

However, upon launching this second reading operation, the judge immediately confronts the limitations of his ability to read. Initially led to believe that the Kojahs are Mahomedan, the ethnographerjudge discovers a wealth of bewildering details pointing in the opposite direction. Although the Kojahs abandoned Hinduism four hundred years ago, Hinduism resembles "the black soil in the Deccan, which . . . convert[s] all foreign substances brought into contact with it into its own material",42 the Kojahs are Hindu in manners, dress, and appearance; 43 "even to the blood of their saint [the Kojahs] adhere by a frail tenure"; 44 "they call themselves Shías to a Shía, and Sunníys to a Sunniy, and they probably neither know nor care any thing as to the distinctive doctrines of either of these great divisions of the Mussalmán world";45 "[t]hey have . . . no translation of the Koran into their vernacular language, or into Guzaratí their language of business, [despite] the long succession of pious Mussalmán kings who reigned in Guzarat"; 46 they can claim no scholar possessing a knowledge of Arabic or Persian, the two great languages of Islamic learning; ${ }^{47}$ finally, their only current religious text "appears to be a strong combination of Hindu articles of faith with the tenets of Islam." The lamenting judge-ethnographer becomes openly accusatory:

[T] he cast never seems to have emerged from the obscurity which attends their present history, and the almost total ignorance of letters, of the principles of their religion, and of their own status, which they

41 Id. at II2.

$42 \mathrm{Id}$. at $\mathrm{II} 2-\mathrm{I} 3$.

43 See id. at II2.

${ }_{44} \mathrm{Id}$. at $\mathrm{II}_{3}$ (emphasis added).

$45 \mathrm{Id}$. at 114 .

46 Id.

${ }^{47}$ See id.

48 Id. 
now evince, is probably the same as has always existed among them since they first embraced the precepts of Mahomed. ${ }^{49}$

The Kojahs come to embody the obscurity upon which the judge's sophisticated reading operation runs aground. Their inherent unreadability condemns the judging operation to radical uncertainty, and the judge is powerless before it.

It is evident, of course, that the text has stumbled upon the fundamentally cognitive - but also classically Orientalist and legal - problem of fitting reality into discrete categories. The unreadability of the Kojahs is not an essential, ontological unreadability, but stems from the inadequacy of the categories themselves. The Anglo-Indian legal system, founded upon the myth that the laws of "Hindus" and "Muslims" would be "protected," founders when it confronts groups such as the Kojahs that exist between these categories. The text recognizes this fact when it admits that a group it initially classified as "Mahomedan" does not believe in "some supposed obligatory force in a text called Divine [the Koran]." readings before the unreadability of the colonized, the text makes the following reluctant confession:

It was believed erroneously that the population of India might be classified under the two great heads of Mahomedan and Gentoo . . . . It may be questioned whether one individual in the Legislature, with the exception, perhaps, of Mr. Burke, - was aware of the sectarian differences which distinguished Shía from Sunniy; and not even that great man, we may be assured, was at all conscious that there were millions of inhabitants in India, such as Sikhs, Jains, Parsís, Israelites and others, who had nothing, or next to nothing, in common with Brahminical worship. ${ }^{51}$

However, it is absolutely critical to remember that Anglo-Indian law is not attempting to fit "reality" into its categories. Its reading operation is directed not at "reality" but at the social text of the colonized - a text that Anglo-Indian law has itself forced into creation by imposing Blackstone's evidentiary test upon Indian custom. Furthermore, the unreadability of the Kojahs is nothing more than the fundamental unreadability of the colonized upon which Anglo-Indian law's reading operations are founded. It is absolutely vital that this myth of unreadability be preserved from extinction, even while AngloIndian law continually launches reading operations against it.

Anglo-Indian law reveals its will to preserve the unreadability of the colonized when it is asked to jettison its reading operations. The parties in The Kojahs and Memons' Case, upon learning of their 
unreadability in the eyes of Anglo-Indian law, offer the Court an escape from its dilemma. Instead of wrestling with the ultimately unanswerable question of how to categorize the Kojahs, the Court could simply apply to their case the law of England as the lex loci ("the general law of the place"). 52 If the Kojahs could not be fitted into the categories of "Hindu" and "Muslim," they could simply be governed by English law, which would liberate the Court from its obsession with launching reading operations against the colonized's seemingly fundamental unreadability.

The opinion firmly rejects this suggestion, realizing that the application of English law as the lex loci could potentially put an end to unreadability itself, thereby creating a dangerous breach in the wall between colonizer and colonized. Accordingly, the text declares that English law as the lex loci cannot be applied because "[t]he doctrine of lex loci seems to be one of altogether modern growth, and peculiar to Christendom." 53 This powerful reconsecration of the difference between colonizer and colonized has both essentialist and evolutionary dimensions. First, lex loci, which implies that all individuals within a territory shall be governed by the same law, can only exist unproblematically among "the nations of Europe[,] [which] have such a family character from this similarity of race, institutions, and religion, that the municipal laws of any one Christian country are, without any violence, applicable to every Christian stranger who comes within its jurisdiction . . ." T4 The doctrinal foundations of lex loci vanish when "a Christian and non-Christian nation come in contact."55 Second, lex loci is depicted as possessing an evolutionary dimension. The opinion states that lex loci arose as a result of racial miscegenation within the Roman Empire.56 Early Roman law, however, did not recognize the doctrine, but followed instead the system of administering to Roman citizens their own laws, while appointing a praetor peregrinus for strangers. 57 Just as in the early Roman empire, "in the East, from the oldest times, an immiscible character has been kept up; foreigners are not admitted into the general body and mass of the society of the natives; they continue strangers and sojourners, as all their fathers were."58 The East does not permit the application of one law because it is composed of essentially immiscible peoples. The evolutionary scale along which the East and West, non-Christian and Christian, colonized and colonizer are arranged is evident.

\footnotetext{
52 See id. at 126.

53 Id. at $\mathrm{r} 26$ (emphasis added).

${ }^{54} \mathrm{Id}$. at $\mathrm{I} 27$ (emphasis added).

55 Id.

${ }^{56}$ See id. at 126.

57 See id.

58 Id. at 127.
} 
More noteworthy is the fact that the opinion presents itself as the protector of the immutable immiscibility of the East - in other words, as an agent of non-disruption. It refuses the parties the benefits of English law in order to preserve the East's immiscibility from violence, in order to keep itself out, as it were. It is conspicuous, however, that the havoc that would result from applying English law to the lives of parties hitherto governed by "native" law is never once mentioned as the rationale for non-disruption. Instead, the Court's response to the call to mingle colonizer and colonized under a single law is its enigmatic, but ultimately highly revealing, recourse to immiscibility - not only the immiscibility among Eastern peoples, but also the concealed, and therefore more profound, immiscibility of East and West, which is, of course, nothing but an unmediated invocation of unreadability. The rhetoric of non-disruption conceals, therefore, an insistence that the colonized be maintained, even imprisoned, behind a veil of unreadability, because it is ultimately upon this imprisonment that the imperial rule of law depends.

\section{B. Judging}

Albeit trapped between the unreadability of the colonized and its own determined refusal to erode that unreadability, Anglo-Indian law cannot evade the imperative of pronouncing judgment. Its ultimate escape to judgment lies in a reenactment of the "indecipherable" violence of its foundation - the restaging of the Battle of Plassey in the colonial courtroom. However, rather than appearing abruptly and without warning, this violence is a veritable leitmotiv in the opinion.

Violence lurks in four different places in The Kojahs and Memons' Case. First, it marks the transition from ethnographic discourse to "pure" legal discourse. After acknowledging the existence in fact of the alleged custom, the opinion suddenly reaffirms its naked power to recognize or reject the custom: "These facts having been established, the first question which arises is, whether this peculiar custom of succession which has prevailed from time . . . immemorial amongst these casts, can be sanctioned in a British Court of justice?"59

Second, after embarking upon a discussion of the history of custom in general and of the tolerance of legislatures toward customs dating back to Roman times, the opinion contrasts two contemporary theories of the relationship between custom and law. Thibaut's System des Pandekten Rechts, instantly discredited as the work of a "great mod-

59 Id. at 115 (emphasis added). Of course, there has already been an affirmation of power in forcing the custom through Blackstone's evidentiary test, but this affirmation receives only a passing mention in the opinion. See id. at 120. 
ern civilian," 60 is cited for the notion that a custom acquires the force of law simply by virtue of the intentional adherence and common consent of a class of persons, so long as the custom is not unreasonable and applies to matters left undetermined by the written law. ${ }^{61}$ "Professor Austin, on the other hand," maintains that "[e]very positive law, or rule of positive law, exists as such by the pleasure of the Sovereign."62 A custom without the imprimatur of the sovereign is, therefore, no law at all. The opinion has no difficulty in choosing the more authoritarian of the two theories. Fiercely protective of its territory, it dismisses Thibaut's theory of custom as a source of law. "English law" and "the sound principle of universal law" dictate that a "custom ... require the sanction of the Court, as representing the sovereign authority, before it obtain[s] any legal validity."63 Only Anglo-Indian law may finally determine what is and is not valid.

Third, in response to the plaintiffs' argument that "this Hindu custom of disinheriting daughters, which has been adopted by [the Kojahs], is most unreasonable, and that public policy would dictate the adoption of the wiser rule laid down in the Koran," 64 the opinion points out carefully that "[w]here public policy accords with the wellrecognized track of morality, it is the duty of the Judge to make every decision conform to it[,] but wherever public policy is a matter of controversy, a lawyer should be the last to express any opinion upon it . ..." How Hower, while admitting that the reasonableness of the Kojah custom is "a matter of controversy," the opinion reserves the right to establish the boundaries within which this "controversy" may unfold. The plaintiffs' argument is doomed to failure because "[the] custom for females to take no share in the inheritance is not unreasonable in the eyes of English law; for it accords in great part with the universal custom as to real estates . . . and entirely with some local customs mentioned in Blackstone . . . ."66 The plaintiffs have thus reached the limits of Anglo-Indian law. For all Anglo-Indian law's non-disruptiveness, these limits are unmistakable, inviolable, and English. In uncertain cases, Indian women may not enjoy more extensive rights to property than their English counterparts.

Finally, and this time to pronounce judgment, the opinion resorts to the violence of Anglo-Indian law's very presence in India. As a

60 Id. at II7. A "civilian" is "one who practices or has made a special study of the Roman or modern civil law [especially] as distinguished from the canon law and the English common law." Webster's Third New InTERnational Dictionary 413 (1986).

${ }^{61}$ See The Kojahs and Memons' Case, supra note 25 , at 117 .

62 Id. at II8 (emphasis added).

${ }^{63} \mathrm{Id}$. at IIg.

${ }^{64} \mathrm{Id}$. at $\mathrm{I} 2 \mathrm{O}$.

65 Id.

${ }^{66}$ Id. (typeface altered) (emphasis added). 
last resort, the plaintiffs demand that the deviant custom of the Kojahs be struck down because it is in conflict with "the Divine law as revealed to [the plaintiffs, and presumably all Kojahs, as Mahomedans] by the Koran; [and because] in this respect it is equivalent to a custom in England which conflicts with a subsequent act of Parliament." 67 There can be no other response to this subversive attempt to place the Koran and the British Parliament on an equal footing but a climactic and wholly unmediated return to the violence of the foundation of Anglo-Indian law. Accordingly, the opinion resorts to the terrifying narrative of conquest and subjugation:

When India fell to the arms of the British it was competent to the Legislature to have repealed the whole of the law which the greater part of the inhabitants considered Divine. It might have been very intolerant and tyrannical to have done so....

... But ... the rule laid down in the act of Parliament would have to be enforced. ${ }^{68}$

Thus, the opinion establishes unequivocally that the Divine law of the Mahomedans exists only at the sufferance of the secular power of the colonizer. The secular judge "recognises the existence of divine laws, and their validity in foro conscientice with those to whom they are addressed, or who believe in the revelation containing them"69 but to him they are mere concomitants of the dictates of his sovereign that he apply them.

Therefore, the divine law of the Koran, as incorporated by a putatively "non-disruptive" Anglo-Indian law, is denuded of its divinity and robbed of its mystical authority. This subjugation of the divine law of Muslims reaffirms, reenacts, and even exceeds the merely temporal cataclysm of the Battle of Plassey in I757. In its refusal to recognize the divinity of the Koran, Anglo-Indian law exposes its promise of non-disruption as a strategic and reversible decision adopted only to facilitate the business of ruling (which, by all accounts, it was).

The opinion adds a further indignity to its humiliation of divine Koranic law. Since both Koranic law and the deviant Kojah custom exist at the sufferance of the sovereign, the opinion argues, there is no reason why they should not be placed on exactly the same footing. The plaintiffs' attempt to equate Koranic law with the British Parliament is transformed into Anglo-Indian law's equation of Koranic law with every custom that deviates from it. 
Therefore, it is by transcribing the violence of its founding into the violence of shaking the divinity out of hitherto divine law that Anglo-Indian law concludes The Kojahs and Memons' Case. This outcome is exactly as Derrida describes. ${ }^{70}$ However, unlike the foundational myths of metropolitan law, which obscure law's founding violence, the myth of unreadability - which, as a possible justification of Anglo-Indian law's founding violence, is indistinguishable from it, and therefore ultimately unjustifiable - results in an overt reenactment of law's founding violence. It is hardly surprising, then, that it is the reasoning of The Kojahs and Memons' Case, and not its result, which won it its fame. ${ }^{71}$

\section{CONCLUSION}

How, then, does The Kojahs and Memons' Case draw aside the "veil which shrouds the privacy of Oriental life"?72 Combining within itself both the ethnographic (reading) and judicial (judging) functions of colonial rule, but always founded upon the myth that the colonized are ultimately unreadable, the drive to preserve that myth, and the unavoidable truth that unreadability must always afflict judging, the case "illustrative" of Oriental life becomes a reading/judging operation that repeatedly affirms the presence of colonial rule. Indistinguishable in moments of collapse, and hopelessly entangled at all other times, reading and judging return incessantly to the colonial ethnographerjudge, ultimately fusing with his authority, just as the violence that preserves law is ultimately indistinguishable from the violence that founds it. That is why The Kojahs and Memons' Case, its wealth of "illustrative" ethnographic detail notwithstanding, is not an account of "native" crisis, ${ }^{73}$ but one more elaborately woven tale of colonial rule.

70 See supra p. 17 I7.

71 Although The Kojahs and Memons' Case upholds the validity of custom over textual law, thus setting itself at odds with Anglo-Indian law's general hostility to custom, it was long hailed as one of Anglo-Indian law's "elaborate and classic" legal pronouncements. RoY, supra note 15, at 406 .

72 PERRY, supra note I, at iii.

73 J.C. Masselos, The Kojalts of Bombay: The Defining of Formal Membership Criteria During the Nineteenth Century, in Caste and Social Stratification Among Muslimis in INDIA 97, 106-07 (Imtiaz Ahmad ed., 2d ed. 1978), reveals that The Kojahs and Memons' Case was the expression of a deep political conflict within the Kojah community about its identity, and that Anglo-Indian law was only one of several battlefields on which this conflict was manifested.

For a description of Anglo-Indian law's subsequent dealings with Kojah and Memon custom throughout the nineteenth century, see Roy, cited above in note 15 , at $405-18$. 